\title{
A Comparative Study of the $21^{\text {st }}$ Century Afterschool Center on Education in Elementary Schools in South Texas
}

\author{
Laura Salinas-Vasquez ${ }^{*}{ }^{1}$, Daniella G. Varela, ${ }^{1}$ Maria E. Martinez ${ }^{1}$ \& Don Jones ${ }^{1}$
}

\begin{abstract}
* Corresponding author
E-mail: lasalinas0713@gmail.com

1. Texas A\&M University-Kingsville, Department of Educational Leadership and Counseling, Kingsville, TX, USA
\end{abstract}

\section{Article Info}

Received: October 11, 2020

Revised: November 11, 2020

Accepted: November 30, 2020

\subsection{3/repam.2020.2}

\section{How to cite}

Salinas-Vasquez, L., Varela, D. G., Martinez, M.E. \& Jones, D. (2020). A comparative study of the $21^{\text {st }}$ Century Afterschool Center on Education in elementary schools in south Texas. Research in Educational Policy and Management, 2(2), 19-37. https://doi.org/10.46303/repam.2020.2

\section{Copyright license}

This is an Open Access article distributed under the terms of the Creative Commons Attribution 4.0 International license (CC BY 4.0).

\begin{abstract}
This quantitative study examines the relationship between implementation of the $21^{\text {st }}$ Century Afterschool Centers on Education (ACE) program and fourth grade student performance on the State of Texas Assessment of Academic Readiness (STAAR). Data was collected from public elementary schools in South Texas via the 2018-2019 Texas Academic Performance Report (TAPR) published by Texas Education Agency (TEA) for each campus. The study applied a quantitative, ex-post facto research approach, which analyzed data from fourth grade students enrolled in elementary schools. Results indicated no significant differences in STAAR performance between those campuses, which implemented ACE, and those, which did not. Thus, the findings dictate a need for policymakers' and school leaders' attention to ensure that enrichment programs are implemented with fidelity and appropriately designed to deliberately effect increases in student learning. Future research may seek to determine more effective enrichment program approaches for students in lowperforming, high-minority serving schools.

\section{KEYWORDS}

Student achievement; closing the gaps; Federal programs; enrichment programs.
\end{abstract}




\section{INTRODUCTION}

Academic success in grades 3 through 5 is essential for the educational foundation of a student. As a result of the deficiency in the State of Texas Assessment of Academic Readiness (STAAR) success rate, Texas schools implement enrichment programs in an effort to improve student academic success. One of the initiatives is the $21^{\text {st }}$ Century Afterschool Centers on Education program (ACE). ACE is a program developed to assist in closing achievement gaps by supplementing the established curriculum with innovative and advance educational strategies through academic enrichment. Additionally, ACE is an initiative funded by the federal government to Title I school districts (21st Century Community Learning Centers, n.d.). ACE assists districts in closing academic achievement gaps by supplementing academics in a variety of ways. These methods included remediation, enrichment, STEM (Science, Technology, Engineering, and Mathematics), and the promotion of parental involvement. School districts design plans in accordance with grant requirements applying supplemental learning opportunities to ensure positive enhancement in attendance, behavior, and ultimately an individualized schedule that met the students' academic needs.

The federal government had awarded over 3 billion dollars in grant funding for the $21^{\text {st }}$ Century Afterschool Centers on Education program over the past five years (Funding Status, 2019). Funds were distributed primarily to low-performing school districts serving high poverty students. Those supports were executed through the establishment of learning centers organized to provide academic enrichment programs during non-school hours for children (Funding Status, 2019). Thus, there is a need to determine the impact $21^{\text {st }}$ Century programs have on academic success for students in Texas as measured by state academic achievement assessments. The purpose of this quantitative study was to compare schools implementing the $21^{\text {st }}$ Century Afterschool Centers on Education Program to similar schools without the $21^{\text {st }}$ Century Afterschool Centers on Education Program in order to determine if there was a difference in the performance on the state assessment, STAAR.

\section{Background}

Research finds that schools all across the nation are challenged to effectively meet the needs of an increasingly diverse population of learners (Aydin, Ozfidan \& Carothers, 2017). Achievement gaps exist between student groups especially according to race where White students score higher on standardized assessments than do Hispanic and/or Black students (Vogler, SchrammPate \& Allan, 2019). Accordingly, achievement gaps in Texas indicate that Hispanic students lag behind other populations and ethnic groups as measured by state standardized tests and other performance indicators such as educational attainment, dropout rates, and attendance (Texas Education Agency, 2019). These achievement gaps are compounded by other factors such as student poverty. STAAR scores were notably different between Title I and non-Title I districts. Title I school districts in south Texas served a disproportionate number of low-socioeconomic students compared to non-Title I districts. Title I schools located in South Texas also have a high 
population of Hispanic students. These two realities can hinder the academic success of these students and it is the districts responsibility in affording the students they serve the most appropriately and adequate education (Saphier, 2017).

The public education accountability system centers its focus on determinations of students' academic success based primarily on their performance on standardized tests (Strunc, 2020). Thus, The STAAR test weighs heavily on the public education accountability system in Texas. On the STAAR test, the rigor, content mastery and comprehension required of students can be up to two level above their respected grade (Sahin, Almus, \& Willson, 2017). The accountability system not only affects the perception on the district/campuses of the stakeholders, it also affects the culture and climate of the school (McGee \& Nelson, 2005). The Texas school accountability system encompasses three domains: Student Achievement, School Progress, and Closing the Gaps. In achieving these ratings, the State of Texas allocated a significant amount of money for resources. Texas utilizes Texas Essential Knowledge and Skills (TEKS) for the development and design of the STAAR assessment (Jacoby \& Vasinda, 2014). Curriculum is outlined by standards for subject area, course, and grade level (Jacoby \& Vasinda, 2014). The state standards are designed to guide teachers on grade level specifics and what content needs to be mastered by students in that grade level. Essentially, when the students master the content of the TEKS required at their respected grade level, student performance on STAAR will increase (Jacoby \& Vasinda, 2019).

School districts with a minimum of $40 \%$ low-income students are identified as a Title I school. Title I served more than 3 million students throughout Texas School Districts. School Districts utilized Title I funding to supplement local and state funding (Grant\& Arnold, 2015). These funds are apportioned to ensure all students receive appropriate and equal education, further allowing individuals the opportunities for improved success on state assessments (Nicks, Martin \& Thibodeaux, 2018). The Texas Education Agency (TEA) reported a total of 3,507,107 students enrollment in Texas Title I schools during the 2017-2018 school year. Title I schools with this funding were capable of offering the student population increased supports necessary for academic success. Examples of such support included hiring tutors for interventional purposes, adopting supplemental curriculum, securing specialized resources to meet the needs of all students, and implementing programs to enhance the educational opportunity for all students enrolled (Title I, Part A Program, 2019).

Title I was established to help support districts by providing funds used for more effective resources, programs, and instructional supports to aid in closing the achievement gap (Grant\& Arnold, 2015). However, over 50 years later, this problem still persists (Strunc, 2020; Slamowitz, 2018). The academic achievement gap between the disadvantage and advantaged students is larger than ever (Grant\& Arnold, 2015; McGown \& Slate, 2019). More recently, through the Every Student Succeeds Act (ESSA), guidelines have been refined to ensure these funds are being spent appropriately and effectively (Snyder, Dinkes, Sonnenberg \& Stephen, 2019). ESSA's central aim is to provide high quality educational experiences for all children in a fair and 
equitable manner in order to close achievement gaps (Van Overschelde and Piatt, 2020). Under that premise, funding guidelines are appropriately more stringent. School must adhere to the guidelines and stipulation on spending the allocated funds (Snyder, Dinkes, Sonnenberg \& Stephen, 2019).

\section{Research Questions}

RQ 1: Is there a significant difference in the percent of students who met standard performance on $4^{\text {th }}$ grade STAAR Reading between schools who implement the $21^{\text {st }}$ Century Afterschool Center on Education and those schools which do not?

RQ 2: Is there a significant difference in the percent of met standard performance on $4^{\text {th }}$ grade STAAR Math between schools who implement the $21^{\text {st }}$ Century Afterschool Center on Education and those schools which do not?

RQ 3: Is there a significant difference in the percent of met standard performance on $4^{\text {th }}$ grade STAAR Writing between schools who implement the $21^{\text {st }}$ Century Afterschool Center on Education and that school which do not?

\section{Null Hypotheses}

The analysis portion of this study attempted to confirm the relationship of the implementation of the $21^{\text {st }}$ ACE program and $4^{\text {th }}$ grade student performance on STAAR.

$\boldsymbol{H}_{01}$ : There is no significant difference in the percent of met standard performance on $4^{\text {th }}$ grade STAAR Reading between schools who implement the $21^{\text {st }}$ Century Afterschool Center on Education and those schools which do not.

$\boldsymbol{H}_{\mathbf{0 2}}$ : There is no significant difference in the percent of met standard performance on $4^{\text {th }}$ grade STAAR Math between schools who implement the $21^{\text {st }}$ Century Afterschool Center on Education and those schools which do not.

$\boldsymbol{H}_{03}$ : There is no significant difference in the percent of met standard performance on $4^{\text {th }}$ grade STAAR Writing between schools who implement the $21^{\text {st }}$ Century Afterschool Center on Education and those schools which do not.

\section{Theoretical Framework}

The educational setting at the primary level is crucial as this is where students obtain the foundation for their education. Schools struggle in addressing all student needs academically through primary instructions (Valenzuela, 2005). The theoretical framework for this study is consequential of the body of literature that links after-school activities to educational outcomes. In order to have the most positive impact on those outcomes, highly effective afterschool programs must address safety, parental involvement, delinquency prevention, and positive relationships (Cooper, Valentine, Nye, \& Lindsay, 1999; Gilman, Meyers \& Perez, 2004; Simpkins, 2003). The $21^{\text {st }}$ Century Afterschool Centers on Education implement instructional/ academic programs to supplement the routine functions of the district as a strategy for improved student performance in STAAR (21st Century Community Learning Centers, n.d.). When education systems are supported with a variety of modalities, it is postulated that schools will see academic improvements (Valenzuela, 2005). 
This study sought to determine how the $21^{\text {st }}$ Century Afterschool Centers on Education program impact on student performance in $4^{\text {th }}$ grade STAAR secondary to supplementing the needs of the students (21st Century Community Learning Centers, n.d.). Enrichment programs are implemented to support students in all aspects of their education. When implemented with fidelity, the ACE program produced positive results. This study adds to the knowledge base related to afterschool programs and the student academic success rate.

\section{Literature Review}

Afterschool programs assist students in content mastery (Vandell, Reisner, Brown, Pierce, Dadisman, \& Pechman, 2004) and are generally funded with federal funds, and require adherence to specific guidelines to operate successfully. Kremer, Maynard, Polanin, Vaughn, and Sarteschi (2015) described the need for state and federal governments to provide funding for the increasing need and desire for after school programs in hopes of closing the achievement gap. Highly effective enrichment programs clearly communicate program goals, work to meet locally relevant needs, compliment school-day instruction and learning, communicate well with school staff and leadership, and are designed to combine academic, enrichment, and fun (Chung, 2000). When done well, enrichment programs have a positive effect on student academics because they work in closing academic gaps for students by providing an extension of daily instruction afterschool (Davies \& Peltz, 2012, p.1).

Texas ACE programs are designed to offer free afterschool enrichment programming for students who are classified as economically disadvantaged (About Afterschool Centers on Education, 2018). The goals for all programs involved focus on all four of the following components: academic tutorial to students before and after the normal school hours, implementation of enrichment in science, technology, and arts, implementation of programs to enhance family engagement, and exposure for students to information regarding colleges and careers through guided field trips (About Afterschool Centers on Education, 2018). The primary goal of Texas ACE is to guarantee student success by assisting school districts with student attendance, behavior, and academic achievement (About Afterschool Centers on Education, 2018). Between 2013 and 2014, the Texas ACE program was granted federal funds of over $\$ 102$ million. This allowed the program to serve approximately 122 grantees (About Afterschool Centers on Education, 2018). According to About Afterschool Centers on Education, (2018) students who participated in the Texas ACE program saw a difference in their academic success. In grades 9 and 10 TAKS scores increased in the areas of Reading and Math. In grades 6 through 12' the number of overall discipline occurrences decreased. In grades 4 through 11 the number of absences recorded on each individual student decreased (About Afterschool Centers on Education, 2018).

Enrichment programs have a positive effect on student academics because they work in closing academic gaps for students by providing an extension of daily instruction afterschool (Davies \& Peltz, 2012). Afterschool programs, like Texas ACE, are also found to have positive impacts on student behavior and school relationships (Durlak, Weissberg \& Pachan, 2010). In a 
thorough review of the impact of afterschool programs, Vandell (2013) noted that students who participate in afterschool programs will have improved test scores and grades, better attendance and lower dropout rates, a numerous positive and significant impacts on social and family relations. To that end, Durlak, Weissberg, and Pachan (2010) found that student participation in well-designed afterschool programs can cultivate up to $20 \%$ greater proficiency in math and literacy. Accordingly, Black et al., 2009 found that students who participate in afterschool enrichment programs gain the equivalent of about one month's worth of additional mathematics learning.

Still, examinations of afterschool enrichment programs, namely Texas ACE, have resulted in mixed interpretations of effectiveness. Naftzger, Arellano, Shields, Long, R. Hoepfner, and Diehl (2020) found evidence of a negative correlation between student attendance of Texas ACE afterschool programs and academic achievement, but a positive correlation between attendance and academic achievement the longer the student participated in program services.

\section{METHODOLOGY}

This quantitative study was designed to determine if there is a significant difference between the existing dependent variable, fourth grade STAAR results, and existing independent variable, the $21^{\text {st }}$ Century ACE program. This quantitative study was based on specified populations and these results defined the similarities amongst the students in the population in regards to collected data (Creswell, 1994). A quantitative study was chosen as the research design, and the data to be collected was already in existence for the population.

Data were retrieved from the public TEA website and the Texas Academic Performance Report (TAPR) also published by the TEA. The TAPR is a database of information extracted from the public-school database that stores records of students' STAAR results. The data was in existence at the time of the study, and it was extracted from public web-based interfaces. The student STAAR data was obtained from the Texas Academic Performance Reports (TAPR).The study applied a quantitative, non-experimental, ex-post facto research approach that analyzed data from fourth grade students from elementary schools in South Texas. As a substitute for true experimental research, ex-post factor research is a quasi- experimental design conducted after the fact and appropriate when the event studied has occurred without intervention from the researcher (Simon \& Goes, 2013). A T-Test was conducted to determine whether there were differences between the independent groups. The independent variable was $4^{\text {th }}$ grade campuses participating in the ACE program. A list of campuses that participated in the ACE program was provided through the $21^{\text {st }}$ Century ACE webpage and the TEA grant award page. The list included the campus name, district name, and the region. There was a compiled list of $4^{\text {th }}$ campuses that did not participate in the ACE program. This population of schools was the comparison group for the study. These schools were studied to determine if the ACE program is needed to effect academic success. The data were collected from the 2018-2019 school year. 


\section{Population and Sample}

For this study, the researchers used school districts in South Texas that implemented the $21^{\text {st }}$ Century ACE program and the same number of school districts in South Texas which did not. This research studied a sample group of elementary schools within Title I school districts in South Texas. The sample included a total of 10 elementary schools. Five schools chosen for the study implemented the $21^{\text {st }}$ Century ACE program and five schools did not.

\section{Data Collection}

Data were extracted from the Texas Education Agency (TEA n.d.) website, the State of Texas Assessment of Academic readiness data storage, and from the TAPR databases on the TEA website. The data collected from these reports was utilized to determine the program's effectiveness. TEA requested this data from all Public Schools in the state of Texas. Data was also collected from several different databases that held student information from particular districts within the $21^{\text {st }}$ Century database.

Data collected was focused on students' academic achievement in $4^{\text {th }}$ grade Reading, Math, and Writing STAAR assessments. According to the ACE requirements, the implementation of such programs enhanced the academic performance of students who actively participated (21st Century Community Learning Centers, n.d.). Overall, student performance was recorded for the identified school districts.

Confidentiality of school districts remained the researchers' primary goal. Confidentiality was kept by replacing school names with ID numbers; Therefore, schools were solely identified by numbers. The utilization of Texas Academic Program Report was used to extract student demographics needed as a component of this study. Campuses were separated into two different subject groups. The first subject group contained campuses who participate in after school enrichment programs, and the other group involved campuses who do not participate in after school enrichment programs. These groups were studied on the effects of participating in an afterschool enrichment program, and the impact it had on student performance in meeting state standard on the STAAR.

\section{Reliability and Validity}

Edmonds and Kennedy (2013) referred to implementing a tool that was utilized for measurement that allowed for the data to have validity. The reliability and validity of this study was used to find the dependability of how the data would be acquired. The dependability and legitimacy would depend on the data that was retrieved from the Texas Academic Program Report, The State of Texas Assessment of Academic readiness data storage, and the databases from the $21^{\text {st }}$ Century programs from the districts selected. The reliability is dependent on the continuous submission of formulas that determined student achievement as determined by Texas Education Agency. The information gathered by these databases was collected on a daily basis for all students. Creswell (1994) articulated how the data collected by the databases would conclude whether the information was valid and valuable, and whether it could be used for 
analysis. The reliability and validity of the analysis depended on the data entered by the researchers.

\section{Data Analysis}

Data collected was formatted and imputed into the Statistical Package for the Social Sciences (SPSS) program. The data utilized had multiple dependent variables; therefore, the researcher implemented a T-Test to run the data. The Dependent variables were defined as academic success measured by performance in the STAAR assessment. The independent variable was defined as taking part in the ACE program. The T-Test determined whether there were differences between the independent groups.

\section{RESULTS}

\section{Demography}

A total of ten elementary school campuses from two counties in South Texas were selected for study resulting in a total 873 students' STARR scores as subjects for analysis. The sample size of 10 schools was chosen to ensure that the studied schools had similar demographics. Table 1 provides the descriptive statistics of the campus implementation and non-implementation of the $21^{\text {st }}$ Century Afterschool Centers on Education for $4^{\text {th }}$ grade students included in this study. There were a total of three schools from County 1 and seven schools from County 2 included in the study. In County 1, one school implemented the ACE program while the other two schools did not. In County 2, four schools implemented the ACE program while the other three did not.

Table 1: Descriptive Statistics on the campus implementation and non-implementation of the $21^{\text {st }}$ Century Afterschool Centers on Education for $4^{\text {th }}$ grade students

\begin{tabular}{llll}
$\begin{array}{l}\text { Region One Education Center } \\
\text { Elementary Schools }\end{array}$ & $\begin{array}{l}\text { ACE } \\
\text { Elementary School }\end{array}$ & $\begin{array}{l}\text { Non-ACE } \\
\text { Elementary School }\end{array}$ & Total \\
\hline County 1 & 1 & 2 & 3 \\
County 2 & 4 & 3 & 7 \\
Total & 5 & 5 & 10 \\
\hline
\end{tabular}

Approximately half of these students were enrolled in a campus implementing the $21^{\text {st }}$ Century ACE Program and the other half of these were enrolled in a campus that does not implement the $21^{\text {st }}$ Century ACE Program. To protect the identity of the campuses, the campuses will be identified as ACE and Non-ACE campuses. Table 2 describes campuses student population of $4^{\text {th }}$ Grade students. 
Table 2: Descriptive Statistics on the campus student population implementation and nonimplementation of the $21^{\text {st }}$ Century Afterschool Centers on Education for $4^{\text {th }}$ grade students

\begin{tabular}{llll}
$\begin{array}{l}\text { Region One Education Center } \\
\text { Elementary Schools }\end{array}$ & $\begin{array}{l}\text { Ace } \\
\text { Elementary School } \\
\text { Student Population }\end{array}$ & $\begin{array}{l}\text { Non-Ace } \\
\text { Elementary School } \\
\text { Student Population }\end{array}$ & Total \\
\hline County 1 & 84 & 151 & 234 \\
County 2 & 364 & 345 & 709 \\
Total & 448 & 496 & 5655 \\
\hline
\end{tabular}

The schools included in this study, whether implementing the ACE program or not, and in accordance with Title I eligibility, are all classified as economically disadvantaged schools. Poverty levels for each campus included in the study are illustrated in Table 3 . As the demographics for all schools studies were similar, these factors were not considered in the analysis.

Table 3: Descriptive Statistics on Percent of Economically Disadvantaged Student Enrollment at Studies Campuses

\begin{tabular}{cccc} 
& Campus & District & State \\
\hline $\begin{array}{c}\text { County } 1 \\
\text { School } 1 \text { (ACE) }\end{array}$ & $86.0 \%$ & $82.9 \%$ & $60.6 \%$ \\
School 2 (Non-ACE) & $88.7 \%$ & $89.6 \%$ & $60.6 \%$ \\
School 3 (Non-ACE) & $94.3 \%$ & $89.6 \%$ & $60.6 \%$ \\
County 2 & & & \\
School 1 (ACE) & $90.7 \%$ & $88.5 \%$ & $60.6 \%$ \\
School 2 (ACE) & $95.8 \%$ & $88.5 \%$ & $60.6 \%$ \\
School 3 (ACE) & $94.7 \%$ & $88.5 \%$ & $60.6 \%$ \\
School 4 (ACE) & $84.1 \%$ & $79.6 \%$ & $60.6 \%$ \\
School 5 (Non-ACE) & $99.7 \%$ & $79.6 \%$ & $60.6 \%$ \\
School 6 (Non-ACE) & $90.6 \%$ & $79.6 \%$ & $60.6 \%$ \\
School 7 (Non-ACE) & $88.0 \%$ & $79.6 \%$ & $60.6 \%$ \\
\hline
\end{tabular}


Results of the statistical analysis showed no significant difference in student performance on the $4^{\text {th }}$ Grade STAAR Reading, Math and Writing, in schools which implement the $21^{\text {st }}$ Century Afterschool Centers on Education (ACE) and those which do not. The results of the hypotheses tests are as follows:

$H_{01}$ : There is no significant difference in the percent of met standard performance on $4^{\text {th }}$ grade STAAR Reading between schools who implement the $21^{\text {st }}$ Century Afterschool

Center on Education and those schools which do not.

The results of the statistical analysis revealed that $4^{\text {th }}$ Grade STAAR Reading performance $(M=68.60, S D=8.91)$ at schools with the ACE program had no statistically significant increase or decrease compared to $4^{\text {th }}$ Grade STAAR Reading performance $(M=75.60, S D=8.68$ ) in schools which do not implement the ACE program. Table 4 illustrates these results.

Table 4: Means and Standard Deviations: Student performance in $4^{\text {th }}$ Grade STAAR Reading

\begin{tabular}{llll}
\hline STAAR Subject/Groups & N & M & SD \\
\hline $4^{\text {th }}$ Grade Reading ACE & 5 & 68.60 & 8.91 \\
$4^{\text {th }}$ Grade Reading Non-ACE & 5 & 75.60 & 8.68 \\
\hline
\end{tabular}

$H_{02}$ : There is no significant difference in the percent of met standard performance on $4^{\text {th }}$ grade STAAR Math between schools who implement the $21^{\text {st }}$ Century Afterschool Center on Education and those schools which do not.

The results of the statistical analysis revealed that $4^{\text {th }}$ Grade STAAR Math performance $(M=71.60, S D=10.78)$ at schools with the ACE program had no statistically significant increase or decrease compared to $4^{\text {th }}$ Grade STAAR Math performance $(M=79.40, S D=15.87)$ in schools which do not implement the ACE program. Table 5 illustrates these results.

Table 5: Means and Standard Deviations: Student performance in $4^{\text {th }}$ Grade STAAR Math

\begin{tabular}{llll}
\hline STAAR Subject/Groups & $\mathrm{N}$ & $\mathrm{M}$ & SD \\
\hline $4^{\text {th }}$ Grade Math ACE & 5 & 71.60 & 10.78 \\
$4^{\text {th }}$ Grade Math Non-ACE & 5 & 79.40 & 15.87 \\
\hline
\end{tabular}

$H_{03}$ : There is no significant difference in the percent of met standard performance on $4^{\text {th }}$ grade STAAR Writing between schools who implement the $21^{\text {st }}$ Century Afterschool Center on Education and those schools which do not. 
The results of the statistical analysis revealed that $4^{\text {th }}$ Grade STAAR Writing performance $(M=63.60, S D=11.15)$ at schools with the ACE program had no statistically significant increase or decrease compared to $4^{\text {th }}$ Grade STAAR Writing performance $(M=65.00, S D=15.92)$ in those school not implementing the program. Table 6 illustrates these results.

Table 6: Means and Standard Deviations: Student performance in $4^{\text {th }}$ Grade STAAR Reading, Math, Writing

\begin{tabular}{llll}
\hline STAAR Subject/Groups & N & M & SD \\
\hline $4^{\text {th }}$ Grade Writing ACE & 5 & 63.60 & 11.15 \\
$4^{\text {th }}$ Grade Writing Non-ACE & 5 & 65.00 & 15.92 \\
\hline
\end{tabular}

In addressing the null hypotheses: $\mathrm{H}_{01}, \mathrm{H}_{02}$, and $\mathrm{H}_{03}$, a T-Test was performed. The researchers selected a T-Test for this study as it is the best test to identify if there is a significant difference between groups (Morgan, et. al., 2013). The T-Test in this study was used determine if a significant difference was present between student performance from campuses which implemented the ACE program and those campuses which did not implement the program. The results of the T-Test analysis revealed no significant differences between the two groups; ACE Campuses and Non-ACE-Campuses, in student performance in $4^{\text {th }}$ Grade STAAR Reading, Math, and Writing.

Levene's Test for Equality of Variances for assumption was used as the determinate. Results confirmed the determination of the use of $T$ value was to be used with equal variances assumed or equal variances not assumed. Equal variance assumed was used, based off the significance of $F>.05$. Null Hypothesis were retained as the significant values in this study were greater than .05. These results are illustrated in Table 7.

Table 7: Statistics for Levene's Test for Equality of Variances: $4^{\text {th }}$ Grade Student Performance on STAAR Reading, Math, Writing, in campuses implementing ACE and those campuses which do not.

\begin{tabular}{lllll}
\hline & & $\mathrm{F}$ & Sig. & $\mathrm{T}$ \\
\hline \multirow{4}{*}{$4^{\text {th }}$ Grade STARR Reading } & $\begin{array}{l}\text { Equal variances assumed } \\
\text { Equal Variance not assumed }\end{array}$ & 0.080 & 0.930 & -1.259 \\
& & & -1.259 \\
& $\begin{array}{l}\text { Equal variances assumed } \\
\text { Equal variances not } \\
\text { assumed }\end{array}$ & 0.373 & 0.558 & -0.909 \\
$4^{\text {th }}$ Grade STARR Math & $\begin{array}{l}\text { Equal variances assumed } \\
\text { Equal variances not } \\
\text { assumed }\end{array}$ & 0.349 & 0.571 & -0.161 \\
$4^{\text {th }}$ Grade STAAR Writing & & & -0.161 \\
\hline
\end{tabular}


The null hypotheses were retained for all research questions in this study. According to the statistical results, there was no evidence of statistical differences among $4^{\text {th }}$ Grade STAAR performance in campuses which implemented the ACE program, and those campuses which did not. This information is validated by the information presented in Table 5 . The information reads: $4^{\text {th }}$ Grade STAAR reading performance $(p=0.930), 4^{\text {th }}$ Grade STAAR Math $(p=0.558)$, and $4^{\text {th }}$ Grade STAAR Writing ( $\left.p=0.571\right)$. Values presented for $p$ are noted to be greater than 0.005 .

The researchers found no statistical significant difference among groups, however, when looking at the actual mean, data suggests a possibility of substantial differences. These differences occur in all subject areas where school districts who did not implement the ACE program perform slightly higher than those which implement the ACE Program. The information on Table 8 articulates this conclusion.

Table 8: Group Statistics: $4^{\text {th }}$ Grade Student Performance on STAAR Reading, Math, Writing, in campuses implementing ACE and those campuses which do not.

\begin{tabular}{lllll} 
STAAR Subject/Groups & $\mathrm{N}$ & $\mathrm{M}$ & SD & Std. Error Mean \\
\hline $4^{\text {th }}$ Grade Reading ACE & 5 & 68.60 & 8.91 & 3.982 \\
$4^{\text {th }}$ Grade Reading Non-ACE & 5 & 75.60 & 8.68 & 3.881 \\
$4^{\text {th }}$ Grade Math ACE & 5 & 71.60 & 10.78 & 4.823 \\
$4^{\text {th }}$ Grade Math Non-ACE & 5 & 79.40 & 15.87 & 7.096 \\
$4^{\text {th }}$ Grade Writing ACE & 5 & 63.60 & 11.15 & 4.986 \\
$4^{\text {th }}$ Grade Writing Non-ACE & 5 & 65.00 & 15.92 & 7.120 \\
\hline
\end{tabular}

\section{DISCUSSION}

Student performance on standardized assessments is an approach to ensure that all students are afforded the most appropriate and equal education (Jacob \& Levett, 2003). In school district that are highly populated with low socioeconomic students, funds are awarded to enhance academics by implementation of programs such as the $21^{\text {st }}$ Century After School Centers on Education better known as ACE in Texas. The results of this study however, provided no evidence of significant differences or relationships between student performance in STAAR Reading (RQ1), Math (RQ2), or Writing (RQ3) in schools that implemented the ACE program and schools which did not. 
While the ACE program is broad and implemented at each campus based on the unique needs of the students, a common factor in the utilization and implementation of the program is to enhance student overall success in academics, in this case yielding higher student performance in STAAR Reading, Math, and Writing. Research question \#1 focused on determining if there was a significant difference in the percent of students who met standard performance on $4^{\text {th }}$ grade STAAR Reading between schools who implemented the $21^{\text {st }}$ Century Afterschool Center on Education and those schools which did not. After carefully analyzing the data, there was no finding of a statistical significant difference in student performance on the $4^{\text {th }}$ grade STAAR Reading between schools who implemented the $21^{\text {st }}$ Century Afterschool Center on Education and those schools which did not.

Research question \#2 concentrated on determining if there was a significant difference in the percent of students who met standard performance on $4^{\text {th }}$ grade STAAR Math between schools who implemented the $21^{\text {st }}$ Century Afterschool Center on Education and those schools which did not. The analysis did not provide evidence of a statistical significant difference in student performance on the $4^{\text {th }}$ grade STAAR Math between schools who implemented the $21^{\text {st }}$ Century Afterschool Center on Education and those schools which did not.

Research question \#3 sought to determine if there was a significant difference in the percent of students who met standard performance on $4^{\text {th }}$ grade STAAR Writing between schools who implemented the $21^{\text {st }}$ Century Afterschool Center on Education and those schools which did not. In reviewing the data, the researchers did not find a statistical significant difference in student performance on the $4^{\text {th }}$ grade STAAR Writing between schools who implemented the $21^{\text {st }}$ Century Afterschool Center on Education and those schools which did not.

In summary, there was no evidence of a statistically significant difference in student performance on $4^{\text {th }}$ Grade STAAR Reading (RQ1), Math (RQ2), or Writing (RW3) at campuses implementing the ACE program compared to those campuses which did not implement ACE. Many other studies have inferred an overwhelming gap in student academic success. School Leaders in Title I schools, have searched for methods, resources, and programs to assist their students in closing that achievement gap. The $21^{\text {st }}$ Century Afterschool Centers on education is a systematic approach many schools have used to address this concern. Thus, the significance of the results of this study point to a possible need for a thorough reevaluation of strategy and implementation where results may imply that ACE programs have not influenced student academic success by meeting state standard on STAAR.

The preliminary findings may be viewed as eye opening. The approximate range of funds allocated to school districts for the ACE program run from $\$ 500,000$ to $\$ 1.5$ million for the duration of the grant, depending on the grant awarded to the campuses. This is a significant investment intended to reap student achievement reward. The results of this study however suggest this is not the case. Results may be indicative of the validity and fidelity of the ACE program at the campuses. ACE programs are designed to close achievement gap by providing students the needed extension to the instruction provided daily. By all appearances, and 
according to existing literature, these are effective strategies to positively affect student performance. The disparities in this study may suggest that the ACE programs implemented in the studied South Texas school districts require further reevaluation concerning strategy focus and program outcome intentionality.

Another conclusion for consideration is that results relating to these campuses may not have utilized the ACE program to fully address some of the gaps within the sample populations studied. A critical part in being able to positively affective student learning and growth is being able to meet the students learning needs in individualized ways. This is precisely why differentiation exists in pedagogical training. Thus, in order to effect gains in student achievement, even enrichment programs like ACE cannot be implemented without a thorough assessment of specific and targeted need. The findings of this study may suggest this approach is lacking in certain aspects of program design and implementation. It should be noted that the data and results for this study were not affected by extrinsic motivators offered by the campuses as incentives for student performance. All campuses included in the study use incentive programs.

\section{Implications}

Current literature addressing the impact the ACE program has on student academic success in meeting state standard for student performance on the STAAR is limited. As is thoroughly articulated in the literature, school accountability is depended on several factors, most importantly student academic success (Bernauer, J. \& Cress, K.,1997). Educators are focusing more on ensuring instruction covers test content versus critical skills needed to comprehend and master the content taught (Herman \& Golan, 1993). Because students fail to master all content required, school districts depend on programs such as ACE to assist in closing the achievement gap and in an effort to yield improved student performance on the state assessments (About Afterschool Centers on Education, 2018).

Evidence provided within the parameters of the data for this study explains implementation of the ACE program in the South Texas elementary campuses may have no significant effect on student performance on STAAR and meeting state standards. The elementary schools implementing the ACE program did not score any higher on Met Performance in $4^{\text {th }}$ Grade STAAR Reading, Math or Writing than those Non-ACE elementary schools in the study.

It can be concluded that the campuses implementing the ACE program may not be thoroughly addressing students' needs. Enrichment programs must be deliberate and intentional to best serve the target population and the collective goals. Thus, it may be inferred that campuses may not have extensively studied the academic needs of the students prior to developing the classes offered during the program. The findings of this study suggest that implementation of the ACE program at the campuses may have more emphasis on enrichment hour than academic hour. Subsequently, ACE campuses in this study did not see higher scores on student performance on STAAR. ACE programs are designed to positively influence student 
achievement from various approaches (attendance incentives, parental involvement, supplemental instructions, etc.). The results of this study imply need to ensure that these various approaches are well-balanced and intently focused on the goal of student achievement. Naftzger, Arellano, Shields, Long, R. Hoepfner, and Diehl (2020) found evidence of a negative correlation between student attendance of Texas ACE afterschool programs and academic achievement, but a positive correlation between attendance and academic achievement the longer the student participated in program services. Those findings may provide an explanation for the results of this study in that the studied ACE schools may be focused on attendance at ACE program events but not the long-term, full investment of student engagement needed to positively influence student achievement.

Conversely, the findings of this study may also point to the effectiveness of other programs, such as STEAM Grant, CYD Grant, LISTO Grant, etc. which may be implemented at non-ACE schools. Where the results of the statistical analysis suggest that there is no significant difference between ACE schools and non-ACE schools, the lack of difference may be a result of other initiatives of equal or perhaps more significant impact. Thus, the findings merit a deeper investigation to better understand what non-ACE schools are doing to influence student achievement on the STAAR test.

This research sought to test the body of literature that links after-school activities to educational outcomes. Although the results of this analysis found no linkages, it is important to consider the distinct qualities of highly effective afterschool programs which have proven to effect increases in student achievement. Gilam, Meyers \& Perez (2004) found that structured extracurricular activities that achieve increases in academic motivation and performance are designed with attention to:

$>$ Active engagement and a sense of belonging

$>$ Positive adult relationships

$>$ Developmental and progressive advancement of skills building

$>$ Promotion of individual strengths

$>$ Prevention of delinquent activity

Cooper, Valentine, Nye, \& Lindsay (1999) contended that afterschool activities that are directly related to learning or those which are designed to foster a positive perception of school identity are those which will see increases in student achievement. Schools must work to implement ACE program initiatives with a focus on student need and instructional deficit. The results of this study encourage educators and policy makers to a reflective evaluation of the established ACE programs. Where the results of this analysis denote a potentially ineffective design, a framework for improvement toward established goals is well documented here.

The results can point to the need to determine the effectiveness of their program objectives and determine their effectiveness to close the achievement gap. This information may prove valuable to school leaders, as well as to ACE project directors, ACE campus coordinators, and ACE teachers. The results of this study allows stakeholders from various 
vantage points to identify the areas that need improvement in order to achieve the overall goals of the ACE program. Although results have provided no significant difference in STAAR performance between ACE/Non-ACE campuses, school officials are well-equipped with these results to encourage efforts that are more intentional about the ACE program.

\section{Recommendations for Future Study}

Based on the statistical limitation of the effects of the ACE program on student performance in meeting state standard in $4^{\text {th }}$ Grade STAAR Reading, Math, and Writing, additional research should be considered. Future research is recommended to include a sample size where all campuses have the same number of years implementing the ACE program in order determine the effects of the ACE program on student performance on STAAR and/or to include a broader range of grade levels for a measure of growth. Future research is also recommended to include race/ethnicity, attendance, faculty/staff, and/or gender as independent variables, to include larger geographical population, and/or more schools throughout the state. Future research is recommended to include focus on STAAR Meets and Mastered standard to further analyze the effects of the ACE program on student performance on STAAR. Future researchers may also examine ACE programs that follow a scripted curriculum versus ACE programs that do not, to further analyze the effects of the ACE program on student performance on STAAR.

\section{CONCLUSION}

Educators throughout the state, especially in school where the population is high in low socioeconomic status (Title I), are tasked with the duty of ensuring all students are achieving academically and achievement gaps are closing. School leaders continuously search for better resources, strategies, and programs to support the already established daily instruction. It is imperative for programs such as ACE to impact their students' academics positively. As school districts rely on programs such as ACE to enhance the overall academic success of students, it was important for the study to address the question: Does the implementation of the ACE program significantly impact student performance in STAAR Reading, Math, and Writing in campus in South Texas? The literature explains how the ACE program should be implemented and the goals of the program achieved. For the study, ACE was implemented afterschool in five elementary schools in deep South Texas. The study used five additional schools which did not implement the ACE program. Results provided by the data showing no evidence of significant difference in ACE campuses as opposed to Non-ACE Campuses. As it is imperative for school leaders to make the best informed decision on implementing programs that significantly improve student academic, the findings of this study allows school leaders to reevaluate their implementation and effectiveness of the ACE program. 


\section{Conflict of interest}

The authors declare that they have no conflict of interest. This research did not receive any specific grant from funding agencies in the public, commercial, or non-profit sectors.

\section{REFERENCES}

21st Century Community Learning Centers. (n.d.).

http://tea.texas.gov/Texas_Schools/Support_for_At-

Risk_Schools_and_Students/21st_Century_Community_Learning_Centers/

About Afterschool Centers on Education. (n.d.). https://www.texasace21.org/about-us

Aydin, H., Ozfidan, B., \& Carothers, D. (2017). Meeting the challenges of curriculum and instruction in school settings in the United States. Journal of Social Studies Education Research, 8(3), 76-92

Bernauer, J. \& Cress, K. (1997). How school communities can help redefine accountability assessment. Phi Delta Kappan, 79, 71-75.

Black, A.R., Somers, M-A., Doolittle, F., Unterman, R., \& Grossman, J.B. (2009). The Evaluation of Enhanced Academic Instruction in After-School Programs. National Center for Education Evaluation and Regional Assistance, Institute of Education Sciences, U.S. Department of Education, Washington, DC. ERIC Document Reproduction Service No. ED506725.dur

Chung, A-M. (2000). Working for Children and Families: Safe and Smart After-School

Programs. U.S. Department of Education and U.S. Department of Justice, Washington, DC. ERIC Document Reproduction Service No. ED441579.

Cooper, H., Valentine, J. C., Nye, B., \& Lindsay, J. J. (1999). Relationship between five afterschool activities and academic achievement. Journal of Educational Psychology, 91(2), 369-378.

Creswell, J. W. (1994). Research design: Quantitative \& quantitative approaches. Thousand Oaks, CA, US: Sage Publications, Inc.

Durlak, J. A., Weissberg, R. P., \& Pachan, M. (2010). A meta-analysis of after-school programs that seek to promote personal and social skills in children and adolescents. American journal of community psychology, 45(3), 294-309.

Every Student Succeeds Act (ESSA). (n.d.). https://www.ed.gov/essa?src=rn

Grant, C. M., \& Arnold, N. W. (2015). The Title I Program: Fiscal Issues and Challenges. International Journal of Educational Reform, 24(4), 363-375

Gilman, R., Meyers, J., \& Perez, L. (2004). Structured extracurricular activities among adolescents: Findings and implications for school psychologists. Psychology in the Schools, 41(1), 31-41.

Herman, J.L., \& Golan S. (1993). Effects of standardized testing on teaching and schools. Educational Measurement: Issues and Practice, 12(4), 20-25,41-42. 
Kremer, K. P., Maynard, B. R., Polanin, J. R., Vaughn, M. G., \& Sarteschi, C. M. (2014). Effects of after-school programs with at-risk youth on attendance and externalizing behaviors: $\mathrm{A}$ systematic review and meta-analysis. J Youth Adolescence Journal of Youth and Adolescence,44(3), 616-636. doi:10.1007/s10964-014-0226-4.

Jacob, B., \& Levitt, S. (2003). Rotten apples: An investigation of the prevalence and predictors of teacher cheating. Quarterly Journal of Economics, 118(3), 843-877.

Jacoby, P., \& Vasinda, S. (2014) Finding the Common Ground: A Comparison of Writing Expectations and Outcomes Between the Texas Essential Knowledge and Skills and the Common Core State Standards. Texas Journal of Literacy Education, 2(1), 69-85. Retrieved from https://files.eric.ed.gov/fulltext/EJ1110933.pdf

McGown, J. A., \& Slate, J. R. (2019). Differences by Economic Status in Grade 3 Reading Performance: A Texas Multiyear Study. Athens Journal of Education, 6(3). Retrieved from https://eric.ed.gov/?id=EJ1218232.

Naftzger, N., Arellano, B. D., Shields, J., Long, R., Hoepfner, D., \& Diehl, D. (2020). 21st Century Community Learning Centers: Texas Afterschool Centers on Education

Nicks, R. E., Martin, G.E., Thibodeaux, T.N., \& Young, J. K. (2018). The relationship between school districts instructional related expenditures to state exam scores in small, mid-size, and large school districts in Texas. Education Leadership Review, 19(1), 60-76.

Novick, B. (2015). 15 ways to involve 'at-risk parents' in enrichment programs. The Education Digest, 81(1), 14-17. Retrieved from https://login.ezproxy.uta.edu/login?url=http://search.proquest.com.ezproxy.uta.edu/d ocview/1708016071 ?accountid=7117.

Van Overschelde, J. P., \& Piatt, A. N. (2020). US Every Student Succeeds Act: Negative Impacts on Teaching Out-of-Field. Research in Educational Policy and Management, 2(1), 1-22.

Sahin, A., Almus, K., \& Willson, V. (2017). A Comparisons of State Test Performances of Public Schools and A Charter School System in Old and New Testing in Texas. Journal of STEM Education: Innovations \& Research, 18(4), 5-16.

Saphier, J. (2017). The equitable classroom. The Learning Professional, 38(6), 28-31.

Simon, M. K., \& Goes, J. (2013). Ex post facto research. Retrieved September, 25, 2013.

Simpkins, S. (2003). Does youth participation in out-of-school time activities make a difference? The Evaluation Exchange, 9(1), 2-3.

Snyder, T. D., Dinkes, R., Sonnenberg, W., \& Cornman, S. (2019). Study of the Title I, Part A Grant Program Mathematical Formulas. Statistical Analysis Report. NCES 2019-016. National Center for Education Statistics

Strunc, A. R. (2020). Are They Listening? Policymakers and Their Role in Public Education. Research in Educational Policy and Management, 2(1), i-iii.

Szabo, S., \& Sinclair, B. B. (2019, November 1). Readability of the STAAR Test is Still Misaligned. Schooling, 10(1).

TEA 2017 Accountability Manual. (2019). https://tea.texas.gov/2019accountabilitymanual.aspx 
Texas Education Agency. (2017). Enrollment in Texas public schools, (Document No. GE16 601 09). Austin TX: Author. "Title I, Part A Program." Title I, Part A Program. US Department of Education (ED).

Texas Education Agency. (2019). Secondary School Completion and Dropouts in Texas Public Schools 2018-19.

Title I, Part A Program." Title I, Part A Program. US Department of Education (ED), 05 Oct. 2015. US Census Bureau. (2017, August 28). More Than 77 Million People Enrolled in U.S. Schools. Retrieved from https://census.gov/newsroom/press-releases/2017/schoolenrollment.html

Valenzuela, A. (2005). Leaving the children behind: How "Texas-style" Accountability Fails Latino Youth. SUNY Press.

Vandell, D. L. (2013). Afterschool program quality and student outcomes: Reflections on positive key findings on learning and development from recent research. TK Peterson's (Ed.), Expanding Minds and Opportunities, 10-16

Vandell, D. L., Reisner, E. R., Brown, B. B., Pierce, K. M., Dadisman, K., \& Pechman, E. M. (2004). The study of promising after-school programs: Descriptive report of the promising programs. University of Wisconsin, Madison: Wisconsin Center for Education Research. Retrieved June, 16, 2006.

Vogler, K., Schramm-Pate, S., \& Allan, A. (2019). Relationship of Instructional Time Configuration, Gender and Race on Seventh Grade Social Studies Performance. Journal of Social Studies Education Research, 10(4), 1-25. 